\title{
Essential oil of Artemisia vestita exhibits potent in vitro and in vivo antibacterial activity: Investigation of the effect of oil on biofilm formation, leakage of potassium ions and survival curve measurement
}

\author{
CHANG YANG ${ }^{1}$, DONG-HUI HU ${ }^{2}$ and YAN FENG ${ }^{3}$ \\ Departments of ${ }^{1}$ Respiratory Medicine and ${ }^{2}$ Liver Disease, Zhongshan Hospital of Hubei Province; \\ ${ }^{3}$ Department of Pathology, The First Hospital of Wuhan, Wuhan, Hubei 430033, P.R. China
}

Received August 28, 2014; Accepted May 8, 2015

DOI: $10.3892 / \mathrm{mmr} .2015 .4210$

\begin{abstract}
The aim of the present study was to investigate the chemical composition of the essential oil of Artemisia vestita and to determine the antibacterial activity of the essential oil and its two major components, grandisol and 1,8-cineole, against certain respiratory infection-causing bacterial strains, in vitro and in vivo. The chemical composition of the essential oil was analyzed using gas chromatography-mass spectrometry. A micro-well dilution method was used to determine the minimum inhibition concentration (MIC) values of the essential oil and its major constituents. A model of Streptococcus pyogenes infection in mice was used to determine its in vivo activities. Lung and blood samples were obtained to assess bacterial cell counts. Toxicity evaluation of the essential oil and its components was completed by performing biochemical analysis of the serum, particularly monitoring aspartate transaminase, alanine transaminase, urea and creatinine. The essential oil exhibited potent antibacterial activity, whereas the two major constituents were less potent. The essential oil exhibited MIC values between 20 and $80 \mu \mathrm{g} / \mathrm{ml}$, while the values of the two constituents were between 130 and $200 \mu \mathrm{g} / \mathrm{ml}$. Scanning electron microscopy results demonstrated that the essential oil inhibited biofilm formation and altered its architecture. Survival curves indicated that the essential oil led to a reduction in the viability of different bacteria. The essential oil also induced significant leakage of potassium ions from $S$. pyogenes. The essential oil (100 $\mu \mathrm{g} / \mathrm{mouse})$ and grandisol (135 $\mu \mathrm{g} / \mathrm{mouse})$ significantly reduced the number of viable bacterial cells in the lungs $(\mathrm{P}<0.01)$. However, intake of $100 \mu \mathrm{g} /$ mouse of essential oil
\end{abstract}

Correspondence to: Professor Yan Feng, Department of Pathology, The First Hospital of Wuhan, 215 Zhongshan Road, Wuhan, Hubei 430033, P.R. China

E-mail: fengyan331@yahoo.com

Key words: Artemisia vestita, essential oil, Streptococcus pyogenes, grandisol, survival curves or grandisol $135 \mu \mathrm{g} /$ mouse once or twice each day for 9 days did not produce any toxic effects in the mice. In conclusion, the in vitro and in vivo results suggested that the essential oil of A. vestita and one of its major constituents, grandisol, can significantly inhibit the growth of different bacterial strains.

\section{Introduction}

Upper respiratory tract infections (URTIs) are disorders caused by an acute infection, commonly involving the nose, sinuses, pharynx or larynx. The various URTIs include the common cold, sinusitis, laryngitis and pharyngitis (1). URTIs are usually caused by viruses, including rhinovirus, coronavirus, Para influenza virus and adenovirus (2). Certain URTIs also result from bacteria, including Streptococcus pyogenes, Streptococcus pneumoneae, Heamophilus influenzae, Corynebacterium diptheriae, Bordetela pertursis and Bacillus anthracis (3). Bronchitis, which is inflammation of the mucosal membranes of the bronchi, is also caused by certain types of bacteria, with $\sim 10 \%$ of cases caused by bacteria, including Mycoplasma pneumoniae, Chlamydophila pneumoniae, Bordetella perturis and S. pneumoniae $(4,5)$. $S$. pyogenes is a spherical, Gram-positive bacterium, and causes $>700,000,000$ infections worldwide each year and $>650,000$ cases of severe, invasive infections with mortality rates of $25 \%$. S. pyogenes the cause of several important human diseases, ranging from mild skin infections to potentially fatal systemic disorders. Infections typically begin in the throat or skin, with pharyngitis being common in S. pyogenes infection. Infections caused by certain strains of $S$. pyogenes are associated with the release of bacterial toxins, which in certain throat infections results in scarlet fever (6). Certain strains of $S$. pyogenes have now developed resistance to macrolides, tetracyclines and clindamycin, indicating the requirement for novel antibacterial agents (7-10).

Essential oils, which are composed of an odoriferous mixture of monoterpenes, sesquiterpenes and aromatic compounds and are used in naturopathic therapy, are well known for their antimicrobial properties. Essential oils were among the first topical and gastrointestinal antimicrobial agents used by humans. Due to the extensive use of 
conventional antibiotics and synthetic antimicrobial drugs, there has been an increase in the widespread development of drug resistant microorganisms, including methicillin-resistant Staphylococcus aureus (MRSA) and multidrug resistant strains of Klebsiella pneumonia and P. aeruginosa $(11,12)$. Essential oils and their components target bacterial cell walls and cytoplasmic membranes, resulting in permeabilization, which is followed by the loss of ions, reduction of the membrane potential, collapse of the proton pump and depletion of the adenosine triphosphate pool (13-15). Due to their multifunctionality, essential oils have wide applications in medicine and aromatherapy. Essential oils exhibit potent antimicrobial actions against a wide range of Gram-positive and Gram-negative bacteria (16). Essential oils have also traditionally been used for treating respiratory tract infections, and as an ethnic treatment for colds (17-19). Inhalation therapy using essential oils has been used to treat acute sinusitis and acute and chronic bronchitis and it has been reported that inhalation therapy using volatile essential oil vapors enhances the respiratory tract fluid output (20 maintains ventilation and drainage of the sinuses, reduces asthma, and reduces inflammation of the trachea (21-23).

Artemisia vestita Wall, a perennial member of the Artemisia genus in the family Asteraceae is distributed on wasteland and river banks in China and has been widely used in traditional Tibetan and Chinese traditional medicine to treat various inflammatory diseases (24). Several studies have investigated the chemical constituents of $A$. vestita, and a number of flavones, monoterpenes and sesquiterpenoids have been isolated. The chemical composition of the essential oil of A. vestita has also been investigated (24-26). At present, to the best of our knowledge, the in vivo and in vitro antibacterial activity of $A$. vestita against respiratory infection-causing bacteria has not been reported previously, and the detailed mechanism of action of $A$. vestita essential oil on bacteria remains to be fully elucidated. Therefore, the present study is the first on the A.vestita essential oil, in which in vitro and in vivo antibacterial activities against the respiratory infection-causing bacteria, S. pyogenes (ATCC-12344), MRSA, S. pneumoniae (ATCC-2730), K. pneumoniae (ATCC-27853) and H. influenzae (ATCC-33391) are investigated. The effects of the oil on biofilm formation and its architecture, and its effect on leakage of potassium ions $\left(\mathrm{K}^{+}\right)$ from $S$. pyogenes was also investigated. Furthermore, the effect of the essential oil and its major component, grandisol, on hepatotoxic- and nephrotoxic-associated biochemical parameters in a $S$. pyogenes-infected mice model were evaluated.

\section{Materials and methods}

Materials. The major essential oil components, 1,8-cineole and grandisol, were purchased from Merck Millipore (Darmstadt, Germany).

Plant material and essential oil isolation. The aerial components of $A$. vestita were provided by a botanist and the plant was identified by a well-known taxonomist [both Department of Botany, School of Life Sciences, Beijing Normal University (BNU), Beijing, China]. The voucher specimen (CAU-2013-08-29-022) was deposited at the BNU Herbarium. Extraction of the essential oil from the aerial components was performed by hydro-distillation for $3 \mathrm{~h}$ using a essential oil determination (Clevenger-type) apparatus (model, MSAW 0789; Lianyungang Highborn Technology Co., Ltd., Lianyungang, China), as recommended in the European Pharmacopoeia (27). Three samples of the dried aerial components $(200 \mathrm{mg})$ were subjected to hydro-distillation at separate times. The essential oil was collected and dehydrated using anhydrous $\mathrm{Na}_{2} \mathrm{SO}_{4}$ (Sigma-Aldrich, St. Louis, MO, USA), and stored at $4^{\circ} \mathrm{C}$ prior to use.

Essential oil analysis using gas chromatography-mass spectrometry $(G C-M S)$. The essential oil was analyzed using GC-MS. GC-MS analysis was performed on a Varian Gas Chromatograph Series 3800 (Agilent Technologies, Inc., Santa Clara, CA, USA), fitted with a VF-5 ms fused silica capillary column $(60 \times 0.25 \mathrm{~mm}$; film thickness, $0.25 \mu \mathrm{m})$ using split/splitless injection, coupled with a Series 4000 Mass Detector (Agilent Technologies, Inc.) under the following conditions: Injection volume, $0.8 \mu \mathrm{l}$ with split ratio 1:80; helium as a carrier gas at $1.5 \mathrm{ml} / \mathrm{min}$ constant flow; injector temperature, $250^{\circ} \mathrm{C}$; oven temperature, $50-260^{\circ} \mathrm{C}$ at $2^{\circ} \mathrm{C} / \mathrm{min}$. The mass spectra electron impact (EI+) mode was set at $70 \mathrm{ev}$ with an ion source temperature of $260^{\circ} \mathrm{C}$. The mass spectra were recorded between a range of 50-500 atomic mass units. Identification of the essential oil constituents was completed based on the following: The retention index (RI), determined with respect to a homologous series of n-alkanes $\left(\mathrm{C}_{5}-\mathrm{C}_{28}\right.$; PolyScience, Niles, IL, USA) under the same experimental conditions; co-injection with standards (Sigma-Aldrich) and standard isolates; identification using an MS library [NIST 05 and Wiley; NIST/ EPA/NIH Mass Spectral Library with Search Program (data version, NIST 11; software version $2.0 \mathrm{~g}$ ), available online: http://www.nist.gov/srd/nistla.cfm] and comparison with previously reported MS data (28).

Antibacterial assessment, bacterial strains and culture media. S. pyogenes (cat. no. ATCC-12344), MRSA, S. pneumoniae (cat. no. ATCC-2730), Klebsiella pneumoniae (cat. no. ATCC-27853) and Haemophilus influenzae (cat. no. ATCC-33391) were used in the present study. All these bacterial strains were obtained from the State Key Laboratory of Microbial Resources, Institute of Microbiology, Chinese Academy of Sciences (Shanghai, China). Bacterial strains were grown on nutrient agar plates at $37^{\circ} \mathrm{C}$ and maintained on nutrient agar slants. The cell suspension of microorganisms in $0.5 \% \mathrm{NaCl}$ was adjusted to a $0.5 \mathrm{McFarland}$ standard to obtain $\sim 10^{6}$ colony forming units (CFUs) $/ \mathrm{ml}$.

Agar well diffusion assay. An antibacterial susceptibility assay was performed using an agar well diffusion assay. The overnight bacterial cultures were added to $30 \mathrm{ml}$ liquid nutrient agar (Sigma-Aldrich). The contents of the tubes were then transferred onto petriplates. Following 20 min solidification of the agar petriplates at $25^{\circ} \mathrm{C}, 20 \mu \mathrm{l}$ essential oil and each of the two chemical constituents were added to separate wells on the plates and incubated for $24 \mathrm{~h}$ at $37^{\circ} \mathrm{C}$. Following incubation, the antimicrobial efficacy of the essential oil 
and the constituents was measured by calculating the width of the inhibition zone, expressed in $\mathrm{mm}$. All experiments were performed in triplicate. Ciprofloxacin $(10 \mu \mathrm{g} / \mathrm{well}$; Sigma-Aldrich) served as a positive control.

Determination of minimum inhibition concentration (MIC) and minimum bactericidal concentration (MBC). The MICs of the essential oil and the constituents were determined using a micro-well dilution method, recommended by the National Committee for Clinical Laboratory Standards (NCCLS), as previously reported (29). The essential oil and its chemical constituents were serially diluted in $2 \mathrm{mg} / \mathrm{ml}$ dimethyl sulfoxide (DMSO; Sigma-Aldrich) and added to Müeller-Hinton (MH) agar (Sigma-Aldrich) supplemented with 5\% sheep blood medium. A range of concentrations of essential oil $(0.10,1,10,20,40$ and $80 \mu \mathrm{g} / \mathrm{ml})$ of the two constituents $(12.5,25,50,100$ and $200 \mu \mathrm{g} / \mathrm{ml})$ were prepared. The inoculum suspension at a final concentration of $0.5 \times 10^{6} \mathrm{CFU} / \mathrm{ml}$ was added to a 96-well microplate. In the wells of the tenth column, $150 \mu \mathrm{l}$ MH broth was added, which was reserved for the bacterial growth control, while the wells in the eleventh column were reserved for the control of the broth sterility. The final column wells contained $150 \mu 1$ nutrient broth and $5 \mu 1$ inoculum as a negative control. Following incubation for $24 \mathrm{~h}$ at $37^{\circ} \mathrm{C}$, the plates were screened visually for broth turbidity. The MIC was defined as the lowest concentration of essential oil at which the bacteria exhibited no visible growth following $24 \mathrm{~h}$ incubation at $37^{\circ} \mathrm{C}$. The $\mathrm{MBC}$ was defined as the lowest concentration of the essential oil and the components, at which almost all of the bacterial pathogens were killed following $24 \mathrm{~h}$ incubation at $37^{\circ} \mathrm{C}$.

Survival dynamic curves. Survival dynamic procedures were performed, according to NCCLS guidelines with minor modifications. The final concentration of the suspension of the strains was adjusted to $10^{4}-10^{6} \mathrm{CFU} / \mathrm{ml}$. The MIC of the A. vestita essential oil was selected for use in the survival dynamic procedure. Following incubation for $0,0.5,1,1.5$, $2,2.5,3,3.5$ and $4 \mathrm{~h}$ using the broth microdilution method, the liquid contents of the wells $(100 \mu \mathrm{l})$ were removed from the test solution for 10 -fold serial dilution with DMSO. Subsequently, $100 \mu \mathrm{l}$ liquid from each dilution was spread onto the surface of the agar plates and incubated at $37^{\circ} \mathrm{C}$ for $24 \mathrm{~h}$, following which the numbers of $\mathrm{CFU} / \mathrm{ml}$ were counted under a Nikon Eclipse 80 microscope (Nikon Corporation, Tokyo, Japan). The solution containing no essential oil served as a control. Survival curves were constructed by plotting the $\log$ number of $\mathrm{CFU} / \mathrm{ml}$ against time (h).

Scanning electron microscopy (SEM) analysis of biofilm formation and its architecture. The overnight culture of S. pyogenes, grown on $\mathrm{MH}$ agar at $37^{\circ} \mathrm{C}$, was added to a saline solution, containing $0.5 \%$ Tween-80 (Sigma-Aldrich). Different concentrations of the A. vestita essential oil (5, 25 and $50 \mu \mathrm{g} / \mathrm{ml}$ ) were prepared and added to the suspension, which was incubated at room temperature. After $12 \mathrm{~h}$, the bacterial cells were centrifuged at $15,000 \mathrm{x}$ g for $20 \mathrm{~min}$. The bacterial cells were washed with $0.5 \mathrm{~mol} / \mathrm{l}$ Tris-acetate buffer (pH 7.1; Sigma-Aldrich), fixed in Tris-acetate buffer containing $1.2 \%$ glutaraldehyde (Sigma-Aldrich), and were then freeze-dried. The bacterial culture of $S$. pyogenes was then visualized using SEM (Hitachi S-3000H; Hitachi, Ltd., Tokyo, Japan) at magnification, x10,000. The bacterial cell suspension in saline with no essential oil treatment served as a negative control.

Efflux of $\mathrm{K}^{+}$ions from S. pyogenes. The concentrations of $\mathrm{K}^{+}$ions in the cell suspensions were measured using a $\mathrm{K}^{+}$ion selective electrode, as previously described by Cox et al (30). The concentration of total free $\mathrm{K}^{+}$in the $S$. pyogenes suspension was measured following incubation in lysostaphin $(50 \mathrm{mg} / \mathrm{ml})$ at $37^{\circ} \mathrm{C}$ for $30 \mathrm{~min}$, followed by sonication with a Laboratory Continuous Cell Flow Probe Sonicator (SJIA-1500W; Ningbo Yinzhou Sjialab Equipment Co., Ltd., Ningbo, China). Complete lysis was confirmed by microscopic examination (Nikon Eclipse 80).

Animals. In the present study, six newborn mice were selected as they are highly susceptible to bacterial infection (31). All in vivo experiments were performed in compliance with the Guide for Care and Use of Laboratory Animals and approved by the Ethics Committee of the General Hospital of Chengdu Military Region.

Swiss albino mice, weighing $25 \pm 2 \mathrm{~g}$, at the age of 4 weeks were used for the in vivo investigation of the essential oil. The mice were obtained from the Experimental Animal Centre of Sichuan University (Chengdu, China) and were maintained in a temperature- and humidity-controlled room $\left(25 \pm 1^{\circ} \mathrm{C}\right.$ and $50 \%$, respectively) with a 12 -h light/dark cycle. The animals had access to water and solid food ad libitum.

Experimental S. pyogenes infection model. The antibacterial effects of the essential oil and its two major constituents were determined by generating an $S$. pyogenes infection model in the mice, as reported previously (32). The infection was induced as follows: The freshly grown bacterial cultures of S. pyogenes were suspended in Todd Hewitt Broth (Sigma-Aldrich) and incubated at $37^{\circ} \mathrm{C}$ until the log phase was reached. The mice were administered with the bacterial pathogens nasally via dropping $20 \mu \mathrm{l}$ inoculum containing $10^{6} \mathrm{CFU}$ S. pyogenes into each nostril (31).

Treatment protocol design. The mice were divided into different groups, each containing 10 mice: Group 1, control (C); group 2, S. pyogenes-infected (SPI); group 3, SPI + A. vestita essential oil (SPI-AVEO ( $25 \mu \mathrm{g}$ /mouse); group 4, SPI-AVEO (50 $\mu \mathrm{g}$ /mouse; group 5, SPI-AVEO (100 $\mu \mathrm{g} / \mathrm{mouse}$ ); group 6, SPI+ 1,8-cineole (SPI-CN; $135 \mu \mathrm{g} /$ mouse); group 7, SPI + grandisol (SPI-GN; $135 \mu \mathrm{g} /$ mouse). Uninfected mice administered with the different concentrations of the oil and components were also included.

The essential oil and the 1,8-cineole and grandisol components were dissolved in DMSO and administered orally to the mice once/day for 9 days post-infection (p.i) and twice/day for 9 days p.i. The positive control was administered with two doses of ciprofloxacin (GlaxoSmithKline plc, Brentford, UK): 1.0 and $2.0 \mathrm{mg} / \mathrm{mouse}$, as ciprofloxacin has a time frame of action after which its effect diminishes. Ciprofloxacin was administered once/day for 9 days. In all groups, drug treatment started 24 h p.i. At days 3, 6 and 9 p.i., three mice from 
each group were sacrificed via a midline incision and blood ( $2 \mathrm{ml}$ ) and whole lung samples were obtained and sliced into small sections $(\sim 1 \mathrm{~cm}$ each) for bacterial cell counts and biochemical analyses of the serum. The results are presented as the means of three independent experiments.

Bacterial cell counts in blood and lungs. The transfer of bacterial pathogens to the blood stream was monitored using blood samples obtained by cardiac puncture with a heparinized syringe. The samples were plated and bacteria was reported as either negative or positive hemocultures following incubation for $12 \mathrm{~h}$ at $37^{\circ} \mathrm{C}$. The lung samples of the mice were prepared for quantitative estimation of bacterial growth, as reported previously (32). The lungs of the mice were excised, weighed and homogenized in $10 \mathrm{ml}$ sterile peptone water. The homogenate $(0.5 \mathrm{ml})$ was then plated in duplicate for bacterial culture to estimate the number of CFU. S. pyogenes colonies were then counted under a Nikon Eclipse 80 microscope, with the results expressed as the $\log \mathrm{CFU} / \mathrm{g}$ of organ.

Biochemical analysis. The blood from the sacrificed mice was collected in a small plastic tube via cardiac puncture, as described above. The blood samples were centrifuged at $15000 x g$ for $15 \mathrm{~min}$ and the blood sera was collected. To assess the liver and renal functions, alanine transaminase (ALT), aspartate transaminase (AST), urea and creatinine levels were measured. A Hitachi-917 Auto analyzer (Hitachi, Ltd., Los Angeles, CA, USA) with ALT and AST kits were supplied by Roche Diagnostics (Basel, Switzerland) were used to perform the biochemical analysis spectrophotometrically. The samples were analyzed in triplicate in a blinded-manner, in order to acquire data with sensitivity and validity.

Statistical analysis. All experiments were performed in triplicate and the results are expressed as the mean \pm standard deviation. A two-way analysis of variance was used for comparisons and Tukey's test was used to examine differences between the groups. Graphpad Prism version 5.01 (GraphPad Software, Inc., La Jolla, CA, USA) was used to perform statistical analyses and $\mathrm{P}<0.05$ was considered to indicate a statistically significant difference.

\section{Results}

Chemical composition of the essential oil. The yield of the essential oil obtained from the dry aerial parts of $A$. vestita was $\sim 0.8 \% \mathrm{w} / \mathrm{v}$. The chemical components of the essential oil, identified using GC-MS, are presented in Table I and the $\mathrm{GC}-\mathrm{MS}$ total ion chromatogram is shown in Fig. 1. A total of 16 compounds were identified in the A. vestita essential oil, accounting for $96.6 \%$ of the total oil composition. The major components of the essential oil were identified as grandisol (45.12\%), 1,8-cineole (22.5\%), camphor $(5.2 \%)$, $\beta$-caryophyllene $(2.5 \%)$ and germacrene D (5.1\%). A literature review revealed that the various Artemisia essential oils contain $\alpha$-pinene, camphor, borneol, bornyl acetate, artemisia ketone, artemisia alcohol, 1,8-cineole, limonene, 1,8-cineole and grandisol as the major constituents (33-36).
Table I. Chemical components identified in the essential oil of Artemisia vestita.

\begin{tabular}{llcc}
\hline Serial number & \multicolumn{1}{c}{ Compound } & RI & Area \% \\
\hline 1 & $\alpha$-pinene & 931 & 0.92 \\
2 & $\beta$-pinene & 942 & 1.22 \\
3 & Camphene & 952 & 1.21 \\
4 & $\Delta$-3-carene & 966 & 1.45 \\
5 & Artemiseole & 978 & 2.1 \\
6 & 1,8 -cineole & 1,031 & 22.5 \\
7 & Camphor & 1,143 & 5.2 \\
8 & Pinocamphone & 1,159 & 2.1 \\
9 & $\alpha$-terpineol & 1,179 & 0.55 \\
10 & Terpinen-4-ol & 1,188 & 2.1 \\
11 & Grandisol & 1,217 & 45.12 \\
12 & $\alpha$-caryophyllene & 1,454 & 0.95 \\
13 & $\beta$-caryophyllene & 1,454 & 2.5 \\
14 & Germacrene D & 1,486 & 5.1 \\
15 & Caryophyllene oxide & 1,584 & 2.6 \\
16 & $\alpha$-bisabolol & 1,665 & 0.98 \\
Total & & & 96.6 \\
& & &
\end{tabular}

RI, retention index, calculated on an RTX-5 column.

Antibacterial activity. The antibacterial activity of $A$. vestita essential oil and its major constituents, 1,8-cineole and grandisol, were evaluated against a set of clinically significant, respiratory infection-causing bacterial strains. These included S. pyogenes, MRSA, S. pneumoniae, K. pneumoniae and $H$.influenzae. The potencies of the essential oil and the chemical constituents were assessed by measuring the inhibition zones and MIC. The results are presented in Table II (MIC and MBC values). The results indicated that the essential oil of $A$. vestita and its major constituents exhibited a broad spectrum and variable degree of antibacterial activity against the various strains. The essential oil exhibited potent growth inhibition against S.pyogenes (MIC, $20 \mu \mathrm{g} / \mathrm{ml}$ ), followed by $H$. influenzae (MIC, $26 \mu \mathrm{g} / \mathrm{ml}$ ), S. pneumoniae (MIC, $32 \mu \mathrm{g} / \mathrm{ml}$ ), MRSA bacterial strain (MIC, $65 \mu \mathrm{g} / \mathrm{ml}$ ) and K. pneumoniae (MIC, $80 \mu \mathrm{g} / \mathrm{ml}$ ).

In order to identify which of the chemical compounds of the $A$. vestita essential oil were active against these respiratory bacteria, further in vitro experiments were performed to evaluate the antibacterial effects of the two major constituents (1,8-cineole and grandisol). These two components exhibited lower growth inhibitory effects, compared with the essential oil, on the bacterial strains, with higher MIC/MBC values. $S$. pyogenes was the most susceptible bacteria to the two oil constituents, and the essential oil itself, with 1,8-cineole resulting in an MIC of $132 \mu \mathrm{g} / \mathrm{ml}$ and grandisol with an MIC of $130 \mu \mathrm{g} / \mathrm{ml}$. Grandisol was more effective against all the bacterial strains, with the exception of $K$. pneumoniae, while 1,8-cineole exhibited higher inhibition. The MRSA bacterial strain was the least susceptible strain to the two compounds, with MIC values of 200 (1,8-cineole) and $178 \mu \mathrm{g} / \mathrm{ml}$ (grandisol). The essential oil was substantially more potent, compared with the individual chemical constituents, indicating 
Table II. Antibacterial activities of the Artemisia vestita essential oil and components through the determination of MIC and MBC values.

\begin{tabular}{|c|c|c|c|c|c|c|c|c|}
\hline \multirow{2}{*}{$\begin{array}{l}\text { Bacterial strain } \\
\text { (cat. no.) }\end{array}$} & \multicolumn{2}{|c|}{$\begin{array}{l}\text { Essential oil } \\
\quad(\mu \mathrm{g} / \mathrm{ml})\end{array}$} & \multicolumn{2}{|c|}{$\begin{array}{l}1,8 \text {-cineole } \\
(\mu \mathrm{g} / \mathrm{ml})\end{array}$} & \multicolumn{2}{|c|}{$\begin{array}{c}\text { Grandisol } \\
(\mu \mathrm{g} / \mathrm{ml})\end{array}$} & \multicolumn{2}{|c|}{$\begin{array}{l}\text { Ciprofloxacin } \\
(\mu \mathrm{g} / \mathrm{ml})\end{array}$} \\
\hline & MIC & MBC & MIC & MBC & MIC & MBC & MIC & MBC \\
\hline $\begin{array}{l}\text { Streptococcus pyogenes } \\
\text { (ATCC-12344) }\end{array}$ & 20 & $>20$ & 132 & $>132$ & 130 & $>130$ & 0.8 & $>2$ \\
\hline $\begin{array}{l}\text { Methicillin-resistant } \\
\text { Staphylococcus aureus } \\
\text { (ATCC-43300) }\end{array}$ & 65 & $>65$ & 200 & $>200$ & 178 & $>178$ & 1.2 & $>2.7$ \\
\hline $\begin{array}{l}\text { Streptococcus pneumoniae } \\
\text { (ATCC-2730) }\end{array}$ & 32 & $>32$ & 166 & $>166$ & 132 & $>132$ & 0.6 & $>1.6$ \\
\hline $\begin{array}{l}\text { Klebsiella pneumoniae } \\
\text { (ATCC-27853) }\end{array}$ & 80 & $>80$ & 132 & $>132$ & 144 & $>144$ & 0.9 & 2 \\
\hline $\begin{array}{l}\text { Haemophilus influenzae } \\
\text { (ATCC-33391) }\end{array}$ & 26 & $>26$ & 144 & $>144$ & 130 & $>130$ & 1.0 & 2.3 \\
\hline
\end{tabular}

MIC, minimum inhibitory concentration; MBC, minimum bactericidal concentration. Essential oil and components were serially dissolved in dimethyl sulfoxide.

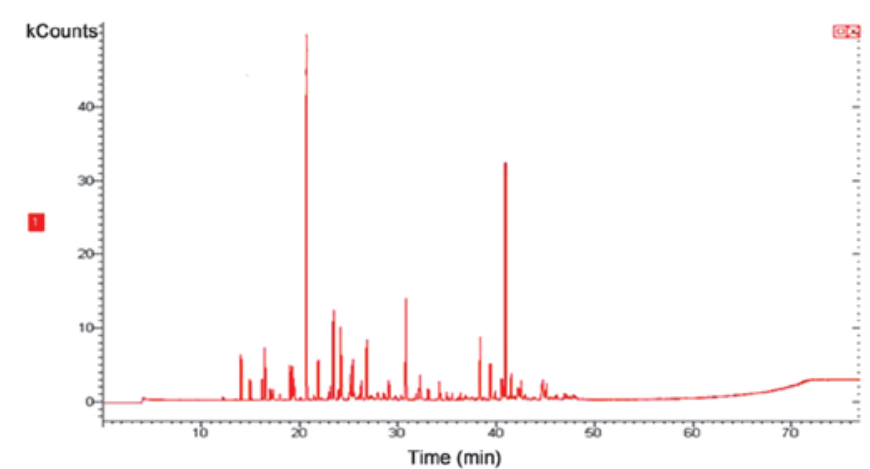

Figure 1. Gas chromatography-mass spectrometry total ion chromatogram of the essential oil of Artemisia vestita. Peaks are representative of the mass of the compounds present in the essential oil.

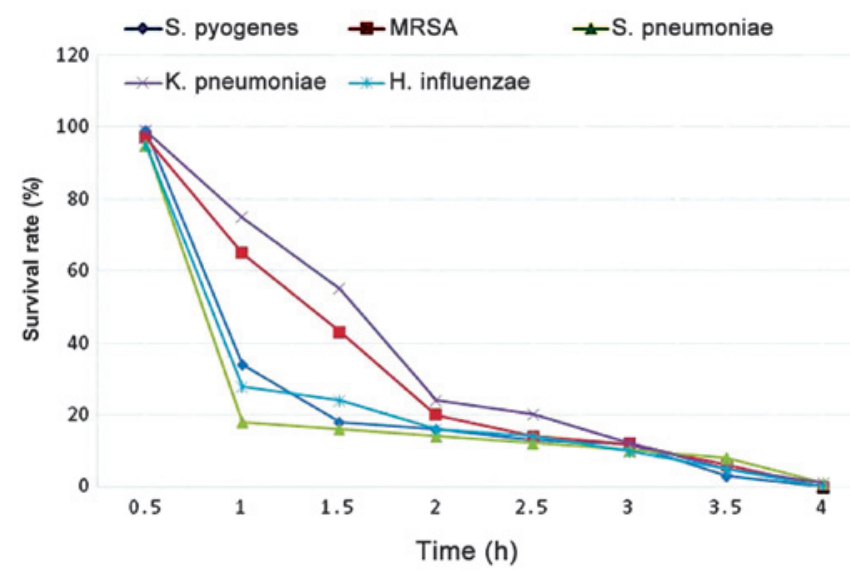

Figure 2. Survival curve determination of different bacterial strains exposed to Artemisia vestita essential oil $(50 \mu \mathrm{g} / \mathrm{ml})$. MRSA, methicillin-resistant Staphylococcus aureus.

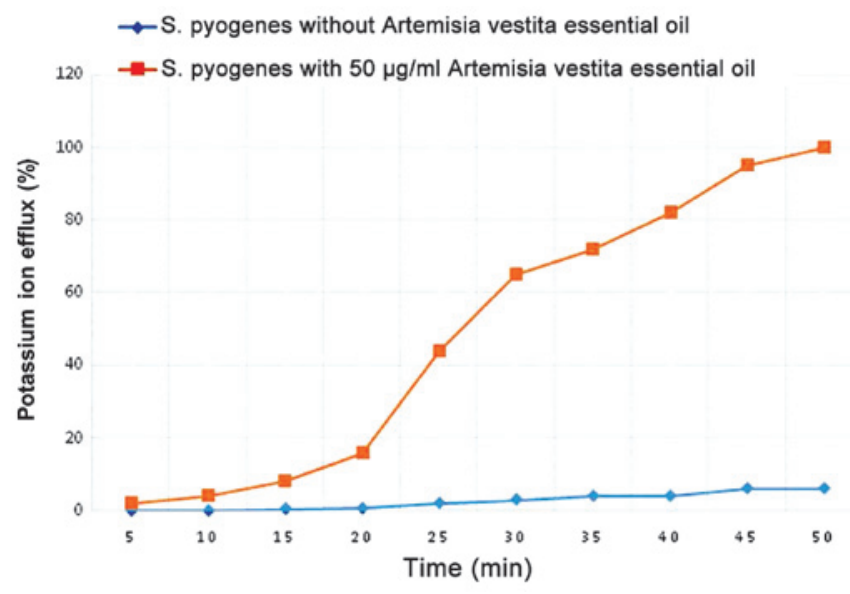

Figure 3. Effects of treatment with $50 \mu \mathrm{g} / \mathrm{ml}$ Artemisia vestita essential oil on the efflux of potassium ions in cell suspensions containing $S$. pyogenes. S. pyogenes, Streptococcus pyogenes.

possible synergy between different chemical constituents of the essential oil.

Survival curve measurement. The survival curves for the essential oil of $A$. vestita on the different bacterial strains is shown in Fig. 2. Measurements of the of induction of death over time by the $A$. vestita essential oil were made for each of the bacterial strains. The essential oil exhibited similar bactericidal effects on all bacterial strains, with $S$. pyogenes and $S$. pneumoniae being the most susceptible to the essential oil. An oil concentration of $50 \mu \mathrm{g} / \mathrm{ml}$ had a bactericidal effect on the pathogen population, resulting in the death of almost $99 \%$ of the bacteria in $4 \mathrm{~h}$.

Measurement of $\mathrm{K}^{+}$leakage from $S$. pyogenes. A. vestita essential oil $(50 \mu \mathrm{g} / \mathrm{ml})$ induced potent leakage of $\mathrm{K}^{+}$ions from 

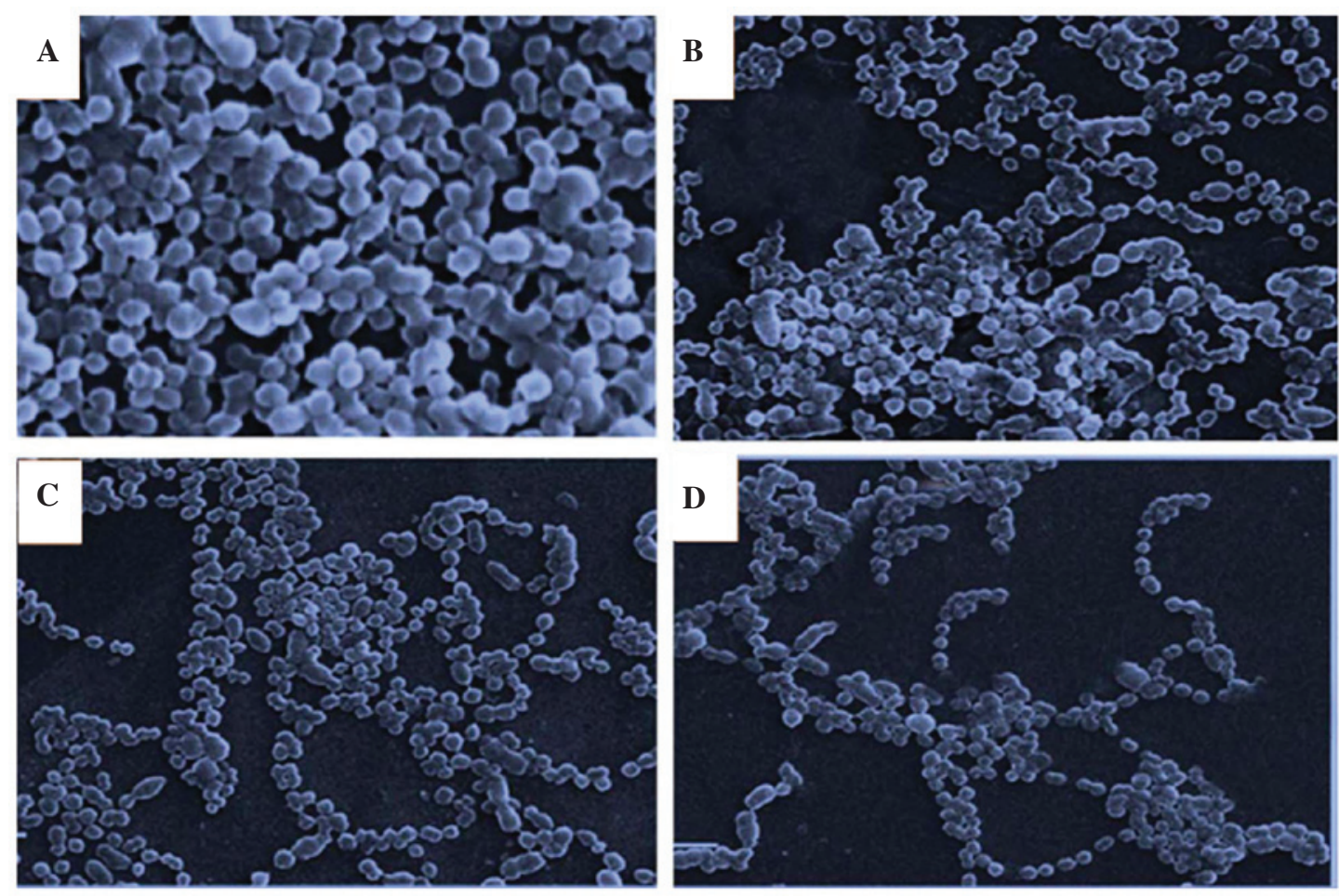

Figure 4. Scanning electron microscopy (magnification, x3,000) demonstrating the effects of different concentrations of Artemisia vestita essential oil on biofilm formation by Streptococcus pyogenes and its architecture. The (A) control and strains exposed to (B) 5 , (C) 25 and (D) $50 \mu \mathrm{g} / \mathrm{ml}$ concentrations of the oil are presented.

S. pyogenes (Fig. 3). The results indicated that the leakage of $\mathrm{K}^{+}$ions started immediately following the addition of $A$. vestita essential oil to the bacterial cultures of S.pyogenes. As Fig. 3 shows, following a time interval of $50 \mathrm{~min}$, the extent of $\mathrm{K}^{+}$ion leakage reached $100 \%$ of the total cellular free $\mathrm{K}^{+}$free ions.

SEM evaluation of the effect of A. vestita oil on $S$. pyogenes biofilm formation and its architecture. SEM investigations were performed on $S$. pyogenes in order to evaluate whether the essential oil of $A$. vestita induces morphological changes in this bacterial strain, and to evaluate the effect of the oil on surface topography and architecture of the biofilms formed by $S$. pyogenes. The results, as shown in Fig. 4, indicated that the essential oil inhibited the biofilm formation of $S$.pyogenes. A total of three different concentrations of the oil $(5,25$ and $50 \mu \mathrm{g} / \mathrm{ml}$ ) were used and it was revealed that $50 \mu \mathrm{g} / \mathrm{ml}$ oil restricted the attachment of bacterial cells of $S$. pyogenes significantly, compared with the control (Fig. 4A). Overall, the effect of the oil on $S$. pyogenes biofilm formation was dose-dependent, exhibiting maximal inhibition at a concentration of $50 \mu \mathrm{g} / \mathrm{ml}$.

In vivo antibacterial activity. The antibacterial efficacies of the essential oil, 1,8-cineole and grandisol were determined using an $S$.pyogenes infection model in mice, as $S$. pyogenes was the most susceptible bacterial strain. The mice were infected with $10^{6}$ CFU S. pyogenes and, after 24 h, the essential oil, 1,8-cineole and grandisol were administered orally to the infected mice. Treatment with higher concentrations of the essential oil (100 $\mu \mathrm{g} / \mathrm{mouse})$ significantly reduced the number of viable $S$. pyogenes bacteria in the lungs, compared with the control. Grandisol treatment $(135 \mu \mathrm{g} /$ mouse) also resulted in loss of viable $S$. pyogenes bacteria (Table III). However, 1,8-cineole, which exhibited significant in vitro inhibition of bacterial growth, had no significant effect at this concentration on the viability of the $S$. pyogenes bacteria in the lungs. The antibacterial efficacy of the essential oil and grandisol was improved when administered twice/day, compared with administration once/day. At lower doses, the essential oil and grandisol were therapeutically less effective against the bacteria. The essential oil- and grandisol-treated groups, and the ciprofloxacin-treated group exhibited negative hemocultures. Therefore, the essential oil and grandisol treatment prevented the spread of $S$. pyogenes infection to the blood.

Biochemical analysis. The possible toxic effects of the active treatment (100 $\mu \mathrm{g}$ essential oil/mouse and $135 \mu \mathrm{g}$ gran$\mathrm{disol} / \mathrm{mouse}$ ) on the hepatic and renal functions were analyzed in mice with and without $S$. pyogenes infection. The activities of the AST and ALT enzymes and the levels of creatinine and urea in the blood did not change following treatment with the essential oil or grandisol in either the mice with or without $S$. pyogenes infection (Table IV). Therefore, the intake of the essential oil (100 $\mu \mathrm{g} /$ mouse) or grandisol (135 $\mu \mathrm{g} /$ mouse) once or twice/day for 9 days produced no toxicity.

\section{Discussion}

The widespread emergence of multi-drug resistant bacteria (MDR) causing different serious infections has led to an urgent requirement for the reassessment of methodologies used to target drug-resistant microbes. Multicomponent 
Table III. Effect of treatment with AVEO, CN and GN in the SPI mouse model.

\begin{tabular}{|c|c|c|c|}
\hline \multirow{2}{*}{$\begin{array}{l}\text { Group } \\
\text { (treatment) }\end{array}$} & \multicolumn{3}{|c|}{$\begin{array}{l}\log _{10} \mathrm{CFU} / \mathrm{g} \text { of organ } \\
\text { post-infection }\end{array}$} \\
\hline & Day 3 & Day 6 & Day 9 \\
\hline SPI & $6.38 \pm 0.24$ & $6.18 \pm 0.11$ & $6.30 \pm 0.02$ \\
\hline $\begin{array}{l}\text { SPI-AVEO } \\
(25 \mu \mathrm{g}-24 \mathrm{~h})\end{array}$ & $6.40 \pm 0.10$ & $6.35 \pm 0.20$ & $6.22 \pm 0.21$ \\
\hline $\begin{array}{l}\text { SPI-AVEO } \\
(25 \mu \mathrm{g}-12 \mathrm{~h})\end{array}$ & $6.35 \pm 0.11$ & $6.20 \pm 0.16$ & $6.23 \pm 0.06$ \\
\hline $\begin{array}{l}\text { SPI-AVEO } \\
(50 \mu \mathrm{g}-24 \mathrm{~h})\end{array}$ & $6.38 \pm 0.41$ & $6.26 \pm 0.16$ & $6.28 \pm 0.12$ \\
\hline $\begin{array}{l}\text { SPI-AVEO } \\
(50 \mu \mathrm{g}-12 \mathrm{~h})\end{array}$ & $6.26 \pm 0.10$ & $6.24 \pm 0.10$ & $5.28 \pm 0.22$ \\
\hline $\begin{array}{l}\text { SPI-AVEO } \\
(100 \mu \mathrm{g}-24 \mathrm{~h})\end{array}$ & $4.66 \pm 0.31^{\mathrm{a}}$ & $4.23 \pm 0.08^{\mathrm{a}}$ & $4.72 \pm 0.32^{\mathrm{a}}$ \\
\hline $\begin{array}{l}\text { SPI-AVEO } \\
(100 \mu \mathrm{g}-12 \mathrm{~h})\end{array}$ & $4.16 \pm 0.21^{\mathrm{b}}$ & $3.92 \pm 0.02^{\mathrm{a}}$ & $4.12 \pm 0.31^{\mathrm{b}}$ \\
\hline $\begin{array}{l}\text { SPI-CN } \\
(135 \mu \mathrm{g}-24 \mathrm{~h})\end{array}$ & $6.35 \pm 0.13$ & $6.22 \pm 0.09$ & $6.12 \pm 0.12$ \\
\hline $\begin{array}{l}\text { SPI-CN } \\
(135 \mu \mathrm{g}-12 \mathrm{~h})\end{array}$ & $6.44 \pm 0.11$ & $5.92 \pm 0.22$ & $6.28 \pm 0.13$ \\
\hline $\begin{array}{l}\text { SPI-GN } \\
(135 \mu \mathrm{g}-24 \mathrm{~h})\end{array}$ & $6.35 \pm 0.22$ & $4.32 \pm 0.11^{\mathrm{b}}$ & $4.77 \pm 0.15^{\mathrm{b}}$ \\
\hline $\begin{array}{l}\text { SPI-GN } \\
(135 \mu \mathrm{g}-12 \mathrm{~h})\end{array}$ & $4.92 \pm 0.07^{\mathrm{a}}$ & $4.52 \pm 0.22^{\mathrm{b}}$ & $4.88 \pm 0.31^{\mathrm{b}}$ \\
\hline $\begin{array}{l}\text { Cip } \\
(50 \mu \mathrm{g}-24 \mathrm{~h})\end{array}$ & $3.92 \pm 0.13^{\mathrm{a}}$ & $3.62 \pm 0.31^{\mathrm{b}}$ & $4.02 \pm 0.14^{\mathrm{a}}$ \\
\hline $\begin{array}{l}\text { Cip } \\
(100 \mu \mathrm{g}-24 \mathrm{~h})\end{array}$ & $3.32 \pm 0.51^{\mathrm{a}}$ & $3.52 \pm 0.12^{b}$ & $3.38 \pm 0.31^{\mathrm{a}}$ \\
\hline Negative control & $7.22 \pm 0.14$ & $7.10 \pm 0.11$ & $7.30 \pm 0.32$ \\
\hline
\end{tabular}

SPI, Streptococcus pyogenes-infected; AVEO, Artemisia vestita essential oil; CN , 1,8-cineole; GN, grandisol; Cip, ciprofloxacin; $\mathrm{CFU}$, colony-forming units. The data are presented as the mean \pm standard deviation. ${ }^{a} \mathrm{P} \leq 0.05 ;{ }^{b} \mathrm{P} \leq 0.01$ vs. negative control.

chemical mixtures and alternative mechanisms of action have renewed interest in the antimicrobial properties of natural antimicrobials, including plant essential oils. Multicomponent compositions of essential oils provide additional benefits in overcoming microbial resistance (37). Several essential oils have demonstrated potent in vitro and in vivo activities against different bacterial pathogens, including those exhibiting antibiotic resistance, for example MRSA and vancomycin-resistant Enterococci. The activities of essential oils against MDR bacteria can be explained by the simultaneous action of the different components on different bacterial targets, and this action is not dependent on target modifications, which lead to antibiotic ineffectiveness (38-40).

A. vestita essential oil and its major constituents have been reported to exhibit antimicrobial activity against 15 different

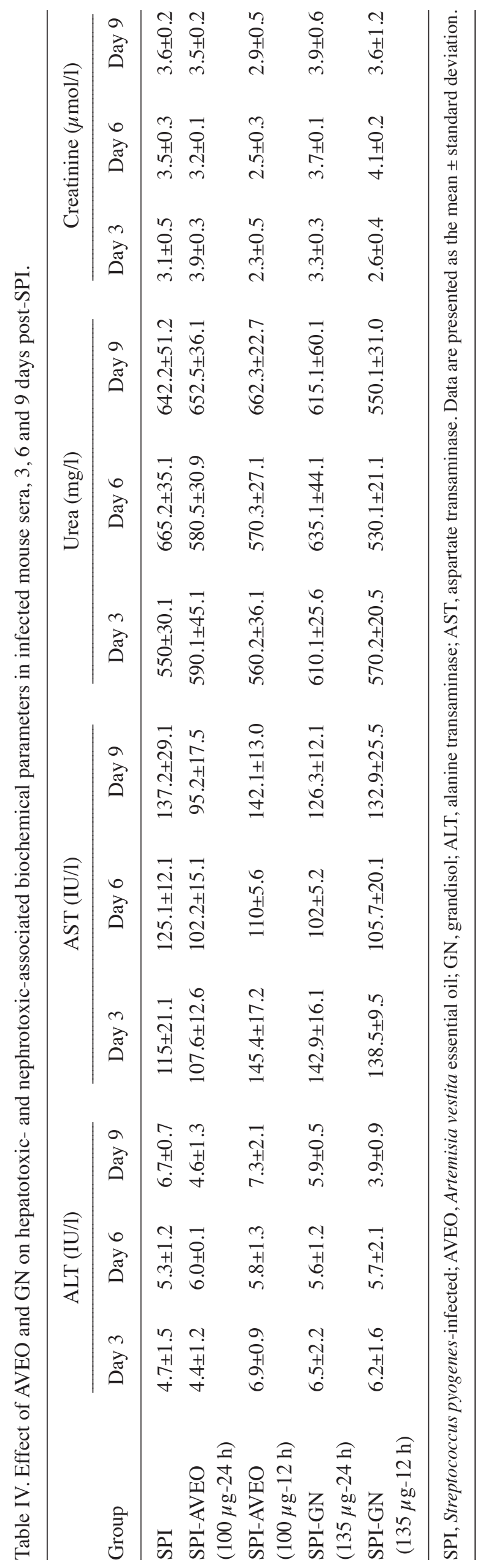


genera of oral bacteria (26), including 1,8-cineole, which has been reported to exhibit potent in vitro antibacterial and antifungal effects against different bacterial and fungal strains (41). To the best of our knowledge, there are no reports on the antibacterial activity of grandisol. In the present study, the in vitro and in vivo antibacterial activity of the A. vestita essential oil and its two major constituents, 1,8-cineole and grandisol, were investigated against common respiratory infection-causing bacterial strains. The essential oil and the two components exhibited potent in vitro bacterial growth inhibition. Survival curve measurements indicated that the essential oil of A. vestita lead to death of almost $99 \%$ of the bacteria within $4 \mathrm{~h}$. The essential oil also induced leakage of $\mathrm{K}^{+}$ions from $S$.pyogenes. SEM indicated that the essential oil of $A$. vestita also inhibited biofilm formation by $S$. pyogenes and altered its architecture.

The in vivo results demonstrated that 1,8-cineole had no in vivo effects on the viability of S. pyogenes in the lungs of the mice. However, treatment with higher concentrations of the essential oil and grandisol significantly reduced the number of viable $S$. pyogenes bacterial cells in the lungs compared with the control. The essential oil (100 $\mu \mathrm{g} / \mathrm{mouse})$ produced therapeutically potent effects in reducing the number of viable bacterial cells of S.pyogenes in the lungs of the mice. A higher concentration of grandisol $(135 \mu \mathrm{g} / \mathrm{ml})$ was required to produce similar bactericidal effects in reducing the number of viable cells in the lungs. The effect of higher concentrations of the essential oil was more significant, compared with that of grandisol.

Toxicological investigations regarding the essential oil and grandisol were also performed. The possible toxic effects of the treatment on hepatic and renal functions in mice were evaluated, and normal levels of AST, ALT, urea and creatinine in blood were observed, suggesting the absence of hepatic or renal damage by the treatment with the essential oil or grandisol.

In conclusion, based on the in vitro and in vivo results of the present study, it was suggested that the A. vestita essential oil and its major component, grandisol, offer potential for development as a novel antibacterial drug for the treatment of respiratory infections, particularly against $S$. pyogenes. Various strains of $S$. pyogenes have now developed resistance to macrolides, tetracyclines and clindamycin, indicating the requirement for novel antibacterial agents, including essential oils. The Food and Drug Administration categorizes essential oils and their components as 'generally regarded as safe' chemicals with few side-effects (42). This fact, coupled with their multicomponent nature, makes essential oils promising candidates for future non-antibiotic anti-infective drugs, since developing resistance against multicomponent agents is difficult.

\section{References}

1. Eccles MP, Grimshaw JM, Johnston M, Steen N, Pitts NB, Thomas R, Glidewell E, Maclennan G, Bonetti D and Walker A: Applying psychological theories to evidence-based clinical practice: Identifying factors predictive of managing upper respiratory tract infections without antibiotics. Implement Sci 2: 26, 2007.

2. Mäkelä MJ, Puhakka T, Ruuskanen O, Leinonen M, Saikku P, Kimpimäki M, Blomqvist S, Hyypiä T and Arstila P: Viruses and bacteria in the etiology of the common cold. J Clin Microbiol 36: 539-542, 1998.
3. Li H, Yang T, Li FY, Yao Y and Sun ZM. Antibacterial activity and mechanism of action of Monarda punctata essential oil and its main components against common bacterial pathogens in respiratory tract. Int J Clin Exp Pathol 7: 7389-7398, 2014.

4. Albert RH: Diagnosis and treatment of acute bronchitis. Am Fam Physician 82: 1345-1350, 2010.

5. Bronchitis, bronchiectasis and cystic fibrosis. In: Infectious Diseases. Cohen J and Powderly W (eds). $2^{\text {nd }}$ edition. Mosby (Elsevier), Orlando, pp444-447, 2004.

6. Cunningham MW. Pathogenesis of group A streptococcal infections. Clin Microbiol Rev 13: 470-511, 2000.

7. Aziz RK, Kansal R, Aronow BJ, Taylor WL, Rowe SL, Kubal M, Chhatwal GS, Walker MJ and Kotb M: Microevolution of group A Streptococci in vivo: Capturing regulatory networks engaged in sociomicrobiology, niche adaptation and hypervirulence. PLoS One 5: e9798, 2010.

8. Wilson LG: The early recognition of Streptococci as causes of disease. Med Hist 31: 403-414, 1987.

9. World Health Organization: The current evidence for the burden of group A streptococcal diseases. http://www.who.int/immunization/documents/WHO_IVB_05.12/en/. Accessed December 15,2014

10. Carapetis JR, Steer AC, Mulholland EK and Weber M: The global burden of group A streptococcal diseases. Lancet Infect Dis 5:685-694, 2005.

11. Yang, Hu DH and Feng Y: Antibacterial activity and mode of action of the Artemisia capillaris essential oil and its constituents against respiratory tract infection-causing pathogens. Mol Med Rep 11: 2852-2860, 2015.

12. Davies J and Davies D. Origins and evolution of antibiotic resistance. Microbiol Mol Biol Rev 74: 417-433, 2010.

13. Rather MA, Dar BA, Dar MY, Wani BA, Shah WA, Bhat BA, Ganai BA, Bhat KA, Anand R and Qurishi MA: Chemical composition, antioxidant and antibacterial activities of the leaf essential oil of Juglans regia L. and its constituents. Phytomedicine 19: 1185-1190, 2012

14. Rashid S, Rather MA, Shah WA and Bhat BA: Chemical composition, antimicrobial, cytotoxic and antioxidant activities of the essential oil of Artemisia indica Willd. Food Chem 138: 693-700, 2013.

15. Bakkali F, Averbeck S, Averbeck D and Idaomar M: Biological effects of essential oils-a review. Food Chem Toxicol 46: 446-475, 2008.

16. Edris AE: Pharmaceutical and therapeutic potentials of essential oils and their individual volatile constituents: A review. Phytother Res 21: 308-323, 2007.

17. Rantzsch U, Vacca G, Dück R and Gillissen A: Anti-inflammatory effects of Myrtol standardized and other essential oils on alveolar macrophages from patients with chronic obstructive pulmonary disease. Eur J Med Res 14 (Suppl 4): 205-209, 2009.

18. Federspil P, Wulkow R and Zimmermann T: Effect of standardized Myrtol in therapy of acute sinusitis - Results of a double-blind, randomized multicenter study compared with placebos. Laryngorhinootologie 76: 23-27, 1997 (In German)

19. Schindl R: Inhalational effect of volatile oils. Wien Med Wochenschr 122: 591-593, 1972 (In German).

20. Boyd EM and Sheppard P: Nutmeg oil and camphene as inhaled expectorants. Arch Otolaryngol 92: 372-378, 1970.

21. Burrow A, Eccles R and Jones AS: The effects of camphor, eucalyptus and menthol vapours on nasal resistance to airflow and nasal sensation. Acta Otolaryngol 96: 157-161, 1983.

22. Shubina LP, Siurin SA and Savchenko VM: Inhalation of essential oils in the combined treatment of patients with chronic bronchitis. Vrach Delo 5: 66-67, 1990 (In Russian).

23. Fröhlich E: Lavender oil, review of clinical, pharmacological and bacteriological studies: Contribution to classification of the mechanism of action. Wien Med Wochenschr 118: 345-350, 1968 (In German).

24. Yin Y, Gong FY, Wu XX, Sun Y, Li YH, Chen T and Xu Q: Anti-inflammatory and immunosuppressive effect of flavones isolated from Artemisia vestita. J Ethnopharmacol 120: 1-6, 2008.

25. Tan RX, Lu H, Wolfender JL, Yu TT, Zheng WF, Yang L, Gafner S and Hostettmann K: Mono- and sesquiterpenes and antifungal constituents from Artemisia species. Planta Med. 65: 64-67, 1999.

26. Chowdhury AR: GC/MS studies of volatiles from Artemisia vestita aerial parts. J Essent Oil-Bearing Plants 6: 210-213, 2003.

27. European Pharmacopoeia Commission: British pharmacopoeia. Vol 1. 3rd edition. Council of Europe, 2001. 
28. Adams RP: Identification of Essential Oil Components by Gas Chromatography/Mass Spectrometry. 4th edition. Allured Publishing Corporation, Carol Stream, pp viii and 804, 2007

29. Ashour ML, El-Readi M, Youns M, Mulyaningsih S, Sporer F Efferth T and Wink M: Chemical composition and biological activity of the essential oil obtained from Bupleurum marginatum (Apiaceae). J Pharm Pharmacol 61: 1079-1087, 2009.

30. Cox SD, Gustafson JE, Mann CM, Markham JL, Liew YC, Hartland RP, Bell HC, Warmington JR and Wyllie SG: Tea tree oil causes K+ leakage and inhibits respiration in Escherichia coli. Lett Appl Microbiol 26: 355-358, 1998.

31. Villena J, Medina M, Racedo S and Alvarez S: Resistance of young mice to pneumococcal infection can be improved by oral vaccination with recombinant Lactococcus lactis. J Microbiol Immunol Infect 43: 1-10, 2010.

32. Racedo S, Villena J, Medina M, Agüero G, Rodríguez V and Alvarez S: Lactobacillus casei administration reduces lung injuries in a Streptococcus pneumoniae infection in mice. Microbes Infect 8: 2359-2366, 2006.

33. Lopes-Lutz D, Alviano DS, Alviano CS and Kolodziejczyk PP Screening of chemical composition, antimicrobial and antioxidant activities of Artemisia essential oils. Phytochemistry 69: 1732-1738, 2008

34. Masoudi S, Rustaiyan A and Vahedi M: Volatile oil constituents of different parts of Artemisia chamaemelifolia and the composition and antibacterial activity of the aerial parts of A. turcomanica from Iran. Nat Prod Commun 7: 1519-1522, 2012 .
35. Habibi Z, Ghanian S, Ghasemi S and Yousefi M: Chemical composition and antibacterial activity of the volatile oil from seeds of Artemisia annua L. from Iran. Nat Prod Res 27: 198-200, 2013.

36. Shafaghat A,Noormohammadi Y and Zaifizadeh M: Composition and antibacterial activity of essential oils of Artemisia fragrans Willd. leaves and roots from Iran. Nat Prod Commun 4: 279-282, 2009.

37. Yap PSX, Yiap BC, Ping HC and Lim SH: Essential oils, a new horizon in combating bacterial antibiotic resistance. Open Microbiol J 8: 6-14, 2014.

38. Kon KV and Rai MK: Plant essential oils and their constituents in coping with multidrug-resistant bacteria. Expert Rev Anti Infect Ther 10: 775-790, 2012.

39. Nelson RR: In-vitro activities of five plant essential oils against methicillin-resistant Staphylococcus aureus and vancomycin resistant Enterococcus faecium. J Antimicrob Chemother 40: 305-306, 1997.

40. Doran AL, Morden WE, Dunn K and Edwards-Jones V: Vapour-phase activities of essential oils against antibiotic sensitive and resistant bacteria including MRSA. Lett Appl Microbiol 48: 387-392, 2009.

41. da Silva AC, Lopes PM, de Azevedo MM, Costa DC, Alviano CS and Alviano DS: Biological activities of $\alpha$-pinene and $\beta$-pinene enantiomers. Molecules 17: 6305-6316, 20-12.

42. Acikgoz ZC, Gocer S and Tuncer S. Macrolide resistance determinants of group A streptococci in Ankara, Turkey. J Antimicrob Chemother 52: 110-112, 2003. 